\title{
Welcome from the SURG editor
}

SURG has now reached an outstanding eight issues! And our tradition of presenting first-rate research from across campus continues.

Our undergraduates continue to be interested in an amazing array of topics whether it be education, international development, food or the environment. In these pages, Guelph students focus on the nature of the mind, Americanization of Canadian Universities and French as a second language in Guelph elementary schools. Other articles delve into globalization and indigenous alcohol abuse, the role women play in forest management in India and factors influencing tourism destination image. Other projects involve gut biodiversity, a strategy for brewers to make use of spent grain and bio-gas, the carbon footprint of Ontario wheat and attitudes toward local food. Other topics include how deaf dolphins in captivity acquire food, the effects of logging on tree diversity patterns in Algonquin park and the effects of silver toxicity in aquatic ecosystems.

Before you start reading, I'd like to thank the student researchers, faculty supervisors, reviewers, journal advisors and our readers. I'd particularly like to thank the new members of our editorial team - this work would not be possible without their exceptional contributions. We look forward to keeping SURG as the premier place to publish undergraduate research in all fields.

Sincerely,

Robert Fieldhouse

Editor-in-Chief 